\title{
Ovarian and reproductive tract responses to vitamin and mineral supplementation in prepubertal gilts
}

\author{
A.J. Zięcik', W. Kapelański' ${ }^{2}$ A. Stępień' , J. Rioperez ${ }^{3}$ \\ and C. de $\mathrm{Alba}^{4}$ \\ 'Institute of Animal Reproduction and Food Research. Polish Academy of Sciences \\ Tuwima 10.10-746 Olsztyn, Poland \\ 'Department of Pig Breeding, University of Technology' and Agriculture \\ Mazowiecka 28, Bydgoszcz, Poland \\ ${ }^{3}$ Instituto de Nutrición y Bromatologia, Facultad de Farmacia, Ciudad Universitaria s/n \\ 280-40 Madrid, Spain \\ ${ }^{4} K U B U S, S . A .$, Calle s/n, Poligono Industrial Európolis \\ 280-230 Las Rozas, Madrid. Spain
}

(Reccived 22 February 2000; accepted 15 July 2000)

\begin{abstract}
The roles of vitamins and minerals in reproductive tract development and attainment of puberty have received very little attention. We examined the effects of vitamin and mineral supplementation on weight and follicular development of ovaries, ovarian concentration of luteinizing hormone (LH) receptors and weight and length of uteri in prepuberal gilts.

Thirty crossbred (Large White x Polish Landrace) 160- (Group I; 75-85 kg) and thirty 180-dayold (Group II: $85-95 \mathrm{~kg}$ ), randomly assigned gilts received $3100 \mathrm{kcal} \mathrm{ME} / \mathrm{kg} / \mathrm{day}$ (control; $\mathrm{n}=15$ ) or supplemented $(n=15)$ with $25 \mathrm{~g}$ of minerals (MMT-Polfa, Kutno, Poland) for 14 days and were slaughtered immediately thereafter. Additionally, both mineral-supplemented subgroups received a single i.m. injection of vitamins $\left(\Lambda, D_{3}, E, B_{1}, B_{2}, B_{6}, B_{12}, C\right.$ and $\left.P P\right)$.

The supplementation treatment did not affect the length of uterine horns or weight of ovaries in either group I or group II. The LH receptor concentration in the ovary ( $\mathrm{fM} / \mathrm{mg}$ protein) was twice as high $(\mathrm{P}<0.05)$ in the supplemented than in control gilts in both group $\mathrm{I}(1.21 \pm 0.25 \mathrm{vs} 2.52 \pm 0.51)$ and II $(1.87 \pm 0.23$ vs $3.77 \pm 0.63)$.

The total number of follicles was $20 \%$ higher in the ovaries of younger gilts (Group I). In the ovaries of younger gilts supplemented with vitamins and minerals, the number of class $1-3 \mathrm{~mm}$ diameter, healthy follicles was significantly higher $(\mathrm{P}<0.05)$. The total number of atretic follicles was
\end{abstract}

' Corresponding author 
$27.5 \%$ lower in this subgroup. No significant changes in number or distribution of healthy and atretic follicles were found among the supplemented- and control animals of the older group (Group II).

The results of this study show that supplementation with vitamins and minerals can influence follicular development and stimulate ovarian LH receptor induction in prepuberal gilts.

KEY WORDS: vitamins, minerals, ovary, LH receptors, reproductive tract, gilts

\section{INTRODUCTION}

In pigs, as in other species, sexual development is related to developmental changes in the ovaries. Ovarian sensitivity to gonadotropins appears very early, approximately in 8-week-old gilts (Oxender et al., 1979). The effect of gonadotropins on ovarian steroid activity (Elsaesser, 1982; Flowers et al., 1989; Jana et al., 1996) and morphological development of ovaries (Kather and Smidt, 1975; Bolamba et al., 1991; Jana et al., 1997) has been well documented. Among pituitary gonadotropins, the pattern of luteinizing hormone $(\mathrm{LH})$ secretion and its action through $\mathrm{LH}$ receptors in the granulosa and theca layers of follicular walls seems to play the most important role in follicular development. The roles of vitamins and minerals in pig reproduction generally, and puberty attainment in particular, have received very little attention (Hughes, 1982). It is very probable that severe restriction of many vitamins and minerals, including vitamin A (Hughes, 1934), vitamin $B_{12}$ (Johnson et al., 1952) and manganese (Plumlee et al., 1956), may delay sexual development.

Our experiment was, therefore, designed to determine whether vitamin and mineral supplementation can affect weight and follicular development of ovaries, ovarian concentration of $\mathrm{LH}$ receptors, weight and length of uteri in prepuberal gilts.

\section{MATERIAL AND METHODS}

Thirty 160-(Group I; 75-85 kg body weight - BW) and thirty 180-day-old (Group II; $85-95 \mathrm{~kg} \mathrm{BW}$ ) crossbred (Large White $\mathrm{x}$ Polish Landrace) gilts kept on basal diet with sufficient protein, vitamins and minerals (Table 1), were randomly assigned to receive $3100 \mathrm{kcal} \mathrm{ME} / \mathrm{kg}$ of feed $(2.5 \mathrm{~kg}$ ) daily (control $\mathrm{C} ; \mathrm{n}=15$ ) or supplemented ( $\mathrm{S} ; \mathrm{n}=15$ ) with $25 \mathrm{~g}$ of minerals containing $\mathrm{Zn}$ (MMT Polfa, Kutno, Poland) for 14 days. Additionally both supplemented subgroups received a single i.m. injection of vitamins (A - $250000 \mathrm{IU}, \mathrm{D}_{3}-125000 \mathrm{IU}, \mathrm{E}-50 \mathrm{mg}, \mathrm{B}_{1}-$ $12.5 \mathrm{mg}, \mathrm{B}_{2}-10 \mathrm{mg}, \mathrm{B}_{6}-6.2 \mathrm{mg}, \mathrm{B}_{12}-15 \mathrm{mg}, \mathrm{C}-10 \mathrm{mg}$ and $62.5 \mathrm{mg}$ of thiamin) on day 1 of the experiment. The animals were maintained in individual stalls under natural lighting and temperature conditions. The experiment was performed on one farm in northeastern Poland. 
TABLE 1

Composition of basal diet*.\%

\begin{tabular}{lc}
\hline Components & \\
\hline Soyabean meal (Central Soya: RT-135) & 15.0 \\
Wheat & 47.5 \\
Barley & 37.5 \\
L-lysine & 0.30 \\
DL-methionine & 0.29 \\
Crude fat & 2.20 \\
Ash & 4.40 \\
Crude protein & 16.2 \\
Crude fibre & 3.00 \\
\hline
\end{tabular}

* basal diet provided per $\mathrm{kg}$ feed: $\mathrm{Ca}-7.8 \mathrm{~g} ; \mathrm{P}-5.6 \mathrm{~g} ; \mathrm{Na}-1.4 \mathrm{~g} ; \mathrm{Fc}-160 \mathrm{mg} ; \mathrm{Cu}-25 \mathrm{mg}$; $\mathrm{Zn}-70 \mathrm{mg} ; \mathrm{Mn}-40 \mathrm{mg} ; \mathrm{J}-0.42 \mathrm{mg}$; Se $-0.25 \mathrm{mg}$ and vitamins: A - $10000 \mathrm{IU} ; \mathrm{E}-40 \mathrm{mg}$; $\mathrm{B}_{1}-3.75 \mathrm{mg}, \mathrm{B}_{6}-1 \mathrm{mg}$ and $\mathrm{B}_{12}-30 \mu$ content of minerals in MMT per kg: $\mathrm{Ca}-170 \mathrm{~g} ; \mathrm{P}-106 \mathrm{~g} ; \mathrm{Na}-38 \mathrm{~g} ; \mathrm{Fe}-3500 \mathrm{mg} ; \mathrm{Cu}-1000 \mathrm{mg}$, $\mathrm{Zn}-5500 \mathrm{mg}, \mathrm{Mg}-3500 \mathrm{mg} ; \mathrm{J}-20 \mathrm{mg}$; Co $-20 \mathrm{mg}$

The gilts were slaughtered on day 15 of the experiment and the reproductive tracts and ovaries were collected and processed. Ovaries collected from each gilt werc wcighed and then one ovary was immediately frozen in liquid nitrogen for further determination of LH receptors. The other ovary was fixed in Bouin's fluid, embedded in paraffin and serially sectioned. Every 50 th section $(6 \mu \mathrm{m})$ was stained with hematoxylin-eosin. In each section all antral follicles were microscopically counted. All mcasured follicles were morphologically classified as healthy or atretic, based on such degencrative changes as the presence of pycnotic nuclei and/or local destruction of the basement membranc. The follicles were divided into two size classes: small, $<1 \mathrm{~mm}$, and medium, 1.1 to $3 \mathrm{~mm}$ in diameter. $\mathrm{LH}$ receptor levels were determined as previously described and validated (Zięcik et al., 1989; Jana et al., 1996).

Briefly, ovaries were thawed, homogenized in six volumes $(\mathrm{v} / \mathrm{w})$ of $25 \mathrm{mmol} / \mathrm{l}$ Tris $\mathrm{HCl}$ buffer $\mathrm{pH} 7.4$ containing $2.50 \mathrm{mmol} / \mathrm{l}$ of sucrose at $4^{\circ} \mathrm{C}$ with an UltraTorax homogenizer. The homogenate was then filtered through four layers of cheesecloth, and the filtrate centrifuged for $20 \mathrm{~min}$ at $800 \mathrm{~g}$ at $4^{\circ} \mathrm{C}$. The resulting supernatant was centrifuged further for $1 \mathrm{~h}$ at $25000 \mathrm{x} g$ at $4^{\circ} \mathrm{C}$ and the sediment sus-

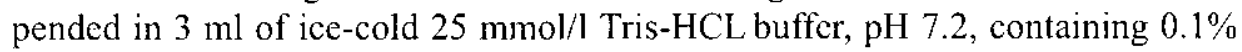
$\mathrm{BSA}$ and $5 \mathrm{mmol} / \mathrm{l} \mathrm{MgCl}_{2}$.

hCG (CR-127) was labelled using the chloramine-T method. Nonspecific binding was measured by the addition of $1 \mathrm{ng}$ unlabelled hCG and was less than $2 \%$ of the total [ $\left.{ }^{125} \mathrm{I}\right]$-labelled hCG added. The concentrations of $\mathrm{LH} / \mathrm{hCG}$, unoccupied binding sites, and association constants $(\mathrm{Ka})$ for hormone binding to receptors were determined using the EBDA computer program (Elsevier BIO-SOFT, Cam- 
bridge, UK). Seven subsaturating quantitics of unlabelled hCG (0.15-5 ng) were used for each receptor preparation as determined according to the method of Lowry et al. (1951).

\section{Data and statistical analysis}

All data were presented as mean \pm SEM and compared by analysis of variance (ANOVA) to establish the overall effect of treatment. In addition, comparisons of means were performed by Duncan's multiple range test or the Bonferroni test.

All calculations were performed using the statistical package GraphPAd PRISM (GraphPad Software, San Diego, CA, USA).

\section{RESULTS}

Vitamin injection and mineral supplementation did not affect the weight or length of uterine horns of either 160- or 180-day-old gilts (Figures 1 a, c). There was also no difference in the weight of ovaries (Figure lb) between control and vitamin- and mineral-supplemented gilts. The LH receptor concentration ( $\mathrm{fM} / \mathrm{mg}$ protein) was two times higher $(\mathrm{P}<0.05)$ in vitamin- and mineral-treated gilts than controls in both group I (control - $1.21 \pm 0.25$ vs. treated $-2.52 \pm 0.51$ ) and II (control $-1.87 \pm 0.23$ vs. treated $-3.77 \pm 0.63$ ). The association constant $(\mathrm{Ka})$ did not differ among groups and ranged between $1.8-2.8 \times 10^{10} \mathrm{l} / \mathrm{mol}$.

The total number of follicles was approximately $20 \%$ higher in the ovaries of the younger (Group I) than older (Group II) gilts in controls as well as in the vitamin- and mineral-treated subgroups. In the ovaries of the treated gilts (Group I, Subgroup $S)$ the number of healthy follicles was significantly higher $(\mathrm{P}<0.05)$ in class of 1-3 mm diameter than in controls (Table 2). The total number of atretic follicles decreased in this subgroup by $27.5 \%$ and healthy/atretic follicles ratios increased from 1.4:1 in controls to $2.0: 1$ in vitamin- and mineral- treated gilts. No significant change in number and distribution of healthy and atretic follicles was found among gilts in Group II given vitamins and supplemented with minerals when compared with controls (Table 2) and the healthy/atretic follicle ratios remained unchanged (2.0:1 in controls vs $2.1: 1$ in treated gilts).

\section{DISCUSSION}

In the conducted trial, the dict of gilts, prior to and during the experiments, was supplied with vitamins and mincrals according to standard nutritional requirements. The excess of vitamins and minerals was applied as „flushing” to alter the repro- 
gilts 160 day of age - control (IC)

$\square$ gilts 160 day of age - vit.and min. supplemented (IS)

gilts 180 day of age - control (IIC)

gilts 180 day of age - vit.and min. supplemented (IIS)
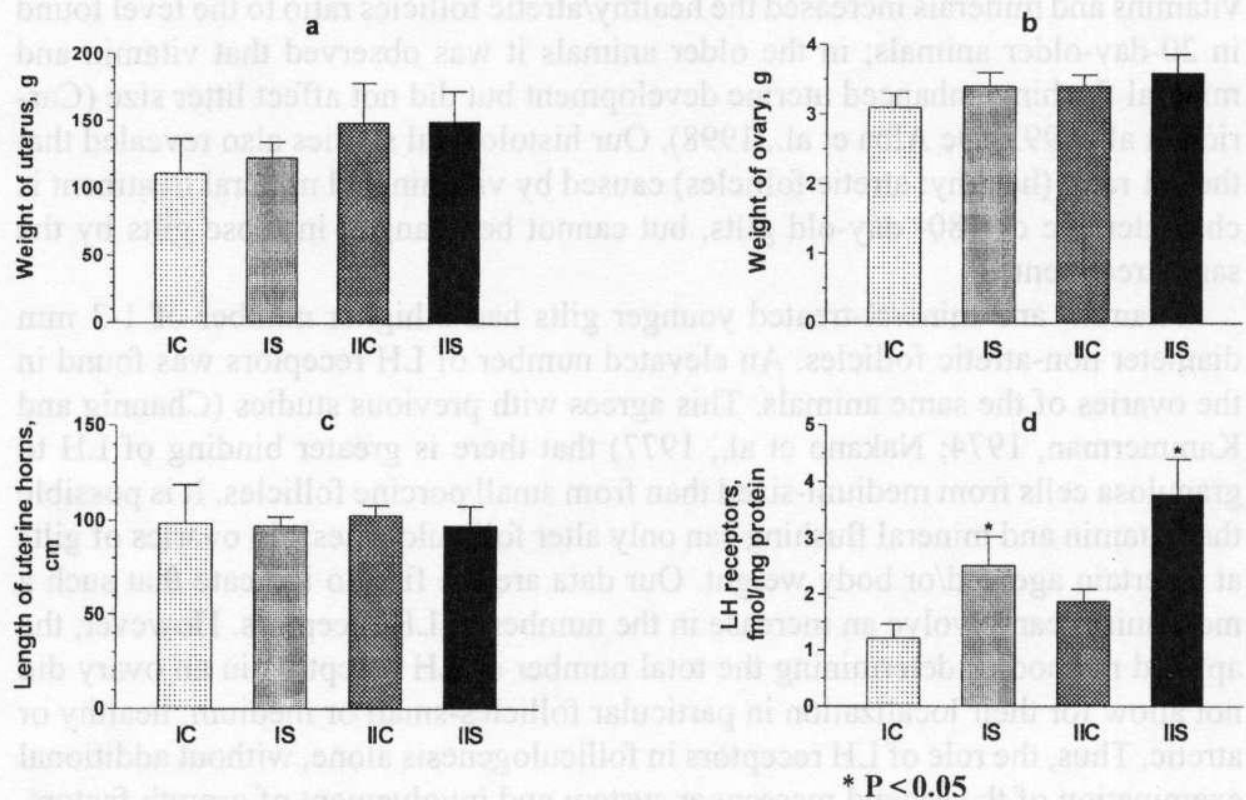

Figure 1. Effects of vitamins and minerals supplementation on weight of ovary (a), weight of uterus (b), length of uterine horns (c) and ovarian LH receptors (d) in 160 (groups IC and IS) and 180 (groups IIC and IIS) days old gilts (mean \pm SEM)

TABLE 2

Number of healthy and atretic follicles in ovaries of 160 and 180 days old gilts supplemented (groups IS and IIS) or not (groups IC and IIC) with vitamins and minerals (every fiftieth $6 \mu \mathrm{m}$ section of one ovary)

\begin{tabular}{|c|c|c|c|c|c|}
\hline \multirow{3}{*}{$\begin{array}{c}\text { Age of gilts } \\
\text { days }\end{array}$} & \multirow{3}{*}{$\begin{array}{c}\text { Group } \\
\mathrm{n}=15\end{array}$} & \multicolumn{4}{|c|}{ Number of follicles on histological sections } \\
\hline & & \multicolumn{2}{|c|}{ healthy } & \multicolumn{2}{|c|}{ atretic } \\
\hline & & $<1 \mathrm{~mm}$ & $1-3 \mathrm{~mm}$ & $<1 \mathrm{~mm}$ & $1-3 \mathrm{~mm}$ \\
\hline \multirow{4}{*}{160} & Control (IC) & $244.4 \pm 33.8$ & $29.2 \pm 3.2^{\mathrm{a}}$ & $180.5 \pm 19.9$ & $19.6 \pm 2.9$ \\
\hline & Vitamins and minerals & & & & \\
\hline & supplemented (IS) & $278.0 \pm 42.6$ & $42.0 \pm 3.8^{b}$ & $134.5 \pm 25.2$ & $22.1 \pm 3.9$ \\
\hline & Control (IIC) & $186.9 \pm 22.9$ & $49.5 \pm 5.6$ & $92.4 \pm 18.6$ & $20.0 \pm 2.6$ \\
\hline \multirow[t]{2}{*}{180} & Vitamins and minerals & & & & \\
\hline & supplemented (IIS) & $224.2 \pm 39.3$ & $47.9 \pm 6.8$ & $93.1 \pm 18.9$ & $23.9 \pm 5.9$ \\
\hline
\end{tabular}


ductive functions in prepuberal gilts. Treating 160- and 180-day old prepubertal gilts with vitamins and minerals did not significantly affect the weight of ovaries and utcri, although a tendency towards a higher weight of ovaries after treatment was found in younger gilts. Also, in the group of 160-day-old gilts, the excess of vitamins and minerals increased the healthy/atretic follicles ratio to the level found in 20-day-older animals; in the older animals it was observed that vitamin and mineral flushing enhanced uterine development but did not affect litter size (Carrión et al., 1993; De Alba et al., 1998). Our histological studies also revealed that the 2:1 ratio (healthy: atretic follicles) caused by vitamin and mineral treatment is characteristic of 180- day-old gilts, but cannot be changed in those gilts by the same treatment.

Vitamin- and mineral-treated younger gilts had a higher number of 1-3 mm diameter non-atretic follicles. An elevated number of LH receptors was found in the ovaries of the same animals. This agrees with previous studies (Channig and Kammerman, 1974; Nakano et al., 1977) that there is greater binding of LH to granulosa cclls from medium-sized than from small porcine follicles. It is possible that vitamin and mineral flushing can only alter folliculogenesis in ovaries of gilts at a certain age and/or body weight. Our data are the first to indicate that such a mechanism can involve an increase in the number of $\mathrm{LH}$ receptors. However, the applied method of determining the total number of LH receptors in an ovary did not allow for their localization in particular follicles-small or medium, healthy or atretic. Thus, the role of $\mathrm{LH}$ receptors in folliculogenesis alone, without additional examination of the second messenger system and involvement of growth factors, cannot be overestimated. On the other hand, the elevated number of $\mathrm{LH}$ receptors in the ovaries of vitamin- and mineral-treated prepubertal gilts suggests that vitamin and mineral treatment can increase the receptivity of ovaries to gonadotropins.

Nothing is known about toxic levels of added vitamins/minerals. In our studics, negative effects on the reproductive tract and ovarian development were not observed.

\section{CONCLUSIONS}

Supplementation of a basal diet with vitamins and mincrals did not influence the weight of the reproductive tract in prepuberal gilts. The addition of vitamins and mincrals can, however, affect follicular development at a certain stage of prepubertal development in gilts. 


\section{REFERENCES}

Bolamba D.. Matton P., Sirard M.A., 1991, Ovarian morphological conditions and the effect of injection of human chorionic gonadotropin on ovulation rates in prepubertal gilts with two morphologically different ovarian types. J. Anim. Sci. 69, 3774-3779

Carrion D., Ewan R., 1993. Kinetics of the alcohol and acetate forms of vitamin E after i.m. and i.v. administration to gilts. Swine Report. Iowa State University, Iowa, pp. 28-30

Channing C.P. Kammerman S.. 1973. Characteristics of gonadotropin receptors of porcine granulosa cell during follicle maturation. Endocrinology 92, 531-540

De Alba C., Fuentes A., Rioperez J., Zięcik A., García C., Martín Rillo S., 1998. Effect of vitamin and mincral flushing (Vit. A, D3, E and Se) on the development of the genital tract, ovary activity and litter size in gilts. Proceedings of $15^{\text {th }}$ IPVS Congress, Birmingham (England), p. 42

Elsaesser F., 1982. Endocrine control of sexual maturation in the female pig and sexual differentiation of the stimulatory ocstrogen feedback mechanism. In: D.J.A. Cole, G.R. Foxcroft (Editors). Control of Pig Reproduction. Butterworths. London, pp. 93-116

Flowers B., Martin M.J., Cantley T.C., 1989. The effect of pregnant mare serum gonadotropin on follicle stimulating hormone and estradiol secretion in the prepubertal gilt. Anim. Reprod. Sci. 21. 93-100

Hughes E.H., 1934. Some effects of vitamin A-deficient diets on reproduction in sows. Agr. Res. 49, 943-953

Hughes P.E., 1982. Factors affecting the natural attainment of puberty in the gilt. In: D.J.A. Cole, G.R. Foxcroft (Editors). Control of Pig Reproduction. Butterworths. London. pp. 117-138

Jana B.. Dusza L., Sobczak J., 1996. Effect of exogenous porcine prolactin (pPRL) on LH plasma concentration and on the relcase of $\mathrm{GnRH}$ in vitro from stalk median eminence in prepubertal gilts. Anim Reprod. Sci. 41, 295-304

Jana B., Dusza L., Sobczak J., Doboszynska T., 1997. Effect of exogenous porcine prolactin on plasma steroid hormones and ovarian morphology in prepubertal gilts. Endocr. Regui. 31, 13-21

Johnsen H.H.K., Moustgaard J., Hojgaard-Olsen N., 1952. The significance of vilamin B 12 for the fertility of sows and gilts. Anim. Breed. Abstr. 23. 784

Kather L., Smidt D., 1975. Vergleichende Untersuchungen zur ovariellen Reaktion infatifer weiblicher Schweine der Deutschen Landrasse des Gttinger Miniaturscheines auf gonadotrope Stimuliering. Zuchthygiene 10, 10-15

Lowry O.H., Rosebrough N.J., Faar A.L., Randal! R.J., 1951. Protein measurement with the Folin phenol reagent. J. Biol. Chem. 193, 265-275

Nakano R., Akahori T., Katayama K., Tojo S., 1977. Binding of LH and FSH to porcine granulosa cells during follicular maturation. J. Reprod. Fertil. 51, 23-27

Oxender W.D., Colenbrander B., van de Wiel D.F.M., Wensing C.J.G.. 1979. Ovarian development in fetal and prepubertal pigs. Biol. Reprod. 21, 715-721

Plumlee M.D., Thrasher D.M., Bceson W.W., Andrews F.N., Parker H.E., 1956. The effects of manganese deficiency upon the growth development and reproduction of swine. J. Anim. Sci. 15. 352-367

Zięcik A.J., Esbenshade K.L., Britt J.H., 1989. Effects of a gonadotrophin-releasing hormone antagonist on gonadotrophin secretion and gonadal development in neonatal pigs. J.Reprod. Fertil. $87,281-289$ 


\section{STRESZCZENIE}

\section{Wplyw witamin i dodatków mineralnych na rozwój ukladu rozrodczego u niedojrzałych plciowo loszek}

Znaczenic witamin i składników mineralnych na rozwój układu rozrodczego i osiagniçcie dojrzałości płciowej zwierząt nic było do tej pory przedmiotem większego zainteresowania. W niniejszej pracy badano wplyw witamin i dodatków mineralnych na ciężar i rozwój jajników, zawartość jajnikowych receptorów hormonu luteinizującego (LH) oraz ciężar i długość macicy u niedojrzałych płciowo loszek.

Trzydzieści loszek mieszańców (Wielka Biała x Polska Biała Zwisłoucha) w wieku 160 (Grupa I; $75-85 \mathrm{~kg}$ ) i trzydzieści w wieku $180 \mathrm{dni}$ (Grupa II; 85-95 kg) dni podzielonych losowo . otrzymywało standardową paszę o zawartości $3100 \mathrm{Kcal} / \mathrm{dzien} / \mathrm{kg}$ (kontrola $\mathrm{n}=15$ ) lub z dodatkiem $25 \mathrm{~g}$ mieszanki mineralnej (MMT-Polfa Kutno; $n=15$ ), przez 14 dni przed ubojem. Dodatkowo zwierzęta z grupy otrzymującej dodatek mieszanki mineralnej otrzymywaly domięśniowo inickcje witamin $\left(A, D_{3}, E\right.$, $\mathrm{B}_{1}, \mathrm{~B}_{2}, \mathrm{~B}_{6}, \mathrm{~B}_{12}, \mathrm{C}$ i PP).

Witaminy i składniki minerałne nic wpłynęły na długość rogów macicy i ciężar jajników w grupach I i II. Zawartość receptorów LH w jajniku (fM/mg białka) była dwukrotnic wiçksza $(\mathrm{P}<0.05)$ u loszek otrzymujących dodatki niż w obu grupach kontroinych - I $(1,21 \pm 0,25$ vs $2,52 \pm 0,51)$ i II $(1,87 \pm 0,23$ vs $3,77 \pm 0,63)$. Ogólna liczba pęcherzyków była o $20 \%$ większa w jajnikach młodszych loszck (Grupa I). W jajnikach tych loszek otrzymujących dodatki mineralne i witaminy liczba zdrowych pęcherzyków była wysoce istotnie wiçksza $(\mathrm{P}<0,5)$ w kłasie l-3 mm średnicy. Jednocześnie liczba pęcherzyków atretycznych była mnicjsza w tej grupie o $27,5 \%$. Nie stwierdzono istotnych zmian liczby i rozmieszczenia pęcherzyków zdrowych i atretycznych u loszek otrzymujących dodatki i w grupic kontrolnej u loszek starszych (Grupa II).

Wyniki tych badań wskazują, że witaminy i dodatki mincralne mogą wpływać na rozwój pęcherzyków i stymulować indukcję reccptorów LH u niedojrzałych piciowo loszck. 